\title{
Influenza delle zone reflessogene vasosensibili sulla funzione vestibolare nel coniglio sottoposto ad elevate accelerazioni trasversali $(*)$
}

\author{
C. VACCA - C. KOCH
}

Ricevuto il 19 Febbraio 1963

Riassunto. - - In esperienze eseguite su conigli di ambo $i$ sessi e del peso medio di $\mathrm{kg} 2$, sottoposti ad accelerazioni trasversali comprese tra 3 e $9-10$ g, prima e dopo la deafferentazione delle zone vasosensibili per taglio dei glossi-faringei, del nervo di Cyon e dei vaghi bilateralmente al collo, is stato studiato il comportamento del nistagmo orizzontale prima, durante e dopo le accelerazioni.

Dalle presenti esperienze pilota. si possono avanzare le seguenti conclusioni:

1. - Nel coniglio normale, sottoposto ad accelerazioni successive di 3,6 e 9-10 g. il $\mathrm{Ny}$ postrotatorio diminuisce sensibilmente per durata. ampiezza e frequenza con l'aumentare delle accelerazioni e, tra di e 9 - $10 \mathrm{~g}$, scompare quasi totalmente mentre durante l'incremento delle accelerazioni si rilevano seosse di " adattamento $\%$. Nel periodo di accelerazione costante ( $90^{\prime \prime}$ per ogni massimale di aceelerazione a 3,6 e $9-10 \mathrm{~g}$ ) non si osservano scosse nistagmiche ad accezione che nella fase ultima allaccelerazione di $3 \mathrm{~g}$.

J'lieg contemporaneamente registrato, dimostra variazioni di frequenza a tipo di adattamento durante l'incremento delle accelerazioni, mentre fondamestalmente la frequenza resta costante nel periodo di stato di essa. Si rilevano inoltre le variazioni già osservate in ricerche di Vacea e coll. durante lo stesso tipo di accelerazioni. nel ratto, e cioc̀: rotazione dell asse elettrico in senso orario, onda P' a tipo anossico e segni di sofferenza coro-

(*) Nota presentata al 20 Congresso Internazionale Teenico Scientifico dello Spazio. Roma, 19-23 Giugno 1962.

$\left(^{* *}\right)$ Istituto di Fisiologia mmana dell'Universiti di Napoli - Direttore Prof. Gino Bergami.

Istituto Medien-Legale per l'Aeronantica Militare di Napoli - Direttore Col. C.S.A. Dr. Giuseppe Pizzuti. 
narica a dipo ischemico. Tali modificazioni scompaiono molto rapidanente subito dopo la fine delle aceelerazioni (in media intorno a $3^{\prime}$ dalla fine della rotazione).

2. - Nel coniglio deafferentato, sottoposto alle stesse accelerazioni su citate, nella fase costante di aceelerazione a $3 \mathrm{~g}$ non si rilevano scosse nistagmiehe che però compaiono, seppure alquanto ridotte di durata, anpiezza e frequenza, alla cessazione della rotazione. A 6 o si nota multeriore riduzione della risposta nistagmica che scompare aldirittura a 9-10 $\mathrm{g}$.

Por quanto riguarda l'Ecog si notano più frequenti e più intense variazioni della frequenza cardiaca sia a volte nel senso di aumentato della frequenza stessa, sia nel senso della riduzione, specie a 6 e $9.10 \mathrm{~g}$ rispetto a quanto osservato prima della deafferentazione. I segni di sofferenza miocardicacoronarica su elencati si accentumo sensibilnente ed il ritorno alla norma, dopo la fine della rotazione, è piò lento. Si è osservato anche un caso di bloceo di branca sinistra. Qualche animale è anche deceduto a $9-10 \mathrm{~g}$.

3. - Je esperienze dimostrano che stimoli afferenti periferici partenti dalle zone vasosensibili cardio-vaso-respiratorie, hanno influenza sulla funzione lahirintica e che la deafferentazione riduce alquanto la resistenza dellanimale alle elevate accelerazioni trasversali.

Sumuar. - In experiments carried out on rabhits of both sexes, weighing a veragely $2 \mathrm{~kg}$, the behaviour of the horizontal Nystagmus hefore, during and after the operations laas been studied. The rabbits were subjected to transversal accelerations between 3,6 and 9- - 0 each, hefore and after the deafferentation of the vasosensitive zones by cutting the glosiopharyngeo, the Cyon nerve and the vagi on both sides of the neck.

From such guide experiments, the following conclusions may be drawn:

1) - In a normal rabbit, subjected to successive accelerations of $3.6 \mathrm{and}$ $9.10 \mathrm{~g}$, the post-rotatory $\mathrm{Ny}$ decreases remarkahly in length, width, and frequency as accelerations increase and it almost disapperas between 6- and 9.10, while during the increase of accelerations "adjustment" oscillations are registered. In the period of costant acceleration $(90 \mathrm{sec}$. for each acceleration maximum at 3,6 and $9-10$ g) no nystagmic oscillations are observed, with the exception of the last phase of $3 \mathrm{~g}$ accelerations.

The Eco recordered at the same time shows frequency variations by the type of aljustment during the increase of accelerations, while frequency remains fundamentally the same during the period of the steady staten variations already observed in former works by Vacea and coll. during the same lind of accelerations in rats, that is: rotation from right to left of the electrical axis; anoxia type $P$ wave, and marks of ischemic type coronary suffering. Such modifieations disappear very quiclily immediately after the end of accelerations (averagely, ahout 3 minutes after the end of the rotation).

2. - In deafferentates rabhits, subjected to the same accelerations as above, no nystagnic oscillations are noticed in the costant acceleration phase at $3 \mathrm{~g}$. Such oscillations however, appear, even if of reduced lenght, 
width, and frequency, at rotation's end. At $6 \mathrm{~g}$. a further decerease of nystagnic response is observed, which totally disappears at $9.10 \mathrm{~g}$.

In the Ege, more frequent and sizeable variations of leart frecumency are noticed, both as increase of the frequency itself and as a clecrease (expecially at 6 and $9-10 \mathrm{~g}$ ) with respect to what observed before deafferentation. The above mentioned marks of myocardium-coronary suffering are remarkably increased and the return to normaly at rotation's end is slower. Also a case of block of the left branch has been observed. Some animals deco. ased also at $9-10 \mathrm{~g}$.

3. - Experiments show that afferents peripherical stimuli, coming from the vasosensitive-cardiac-respiratory zones, have an influence on the labyrinth function and their deafferentation reduce sizeably the animals resistency to high transversal accelerations.

\section{INTRODUZIONE E SCOPO DELLE RICERCIIE.}

İ noto dalla fisiologia classica che l'eceessiva stimolazione labirintica determina riflessi nemo-vegetativi sia a carico del sistema cardio-eircolatorio (pallore, sudorazione, aumento della frequenza cardiaca) sia a carico di altri organi (nausea, vomito, vertigine ece.). Non ci risulta che ricerche più approfondite siano state condotte sull'importanza che le zone reflessogene vasosensibili possano avere, viceversal, sulla funzione restibolatre.

Ci è parso pertanto utile condurre ricerche in tal senso dato che la navigazione spaziale, in atto, sottopone l'astronauta arl intense accelerazioni nella fase di decollo dalla terra ed in quella di rientro nell'atmosferis.

\section{TECNICA ED ESPERIMEN'II.}

Le ricerche somo state condotte su ronigli di ambo i sessi e del peso medio di $2 \mathrm{~kg}$ sottoposti ad accelerazioni trasversali comprese tra 3,6 a 9-10 g, mantenendoli a tali accelerazioni, nella fase massimale per ciascuna di esse, per la durata di $90^{\prime \prime}$. Ia fase di incremento delle accelerazioni ì stata sempre molto lenta e rispettivamente in valori di tempo da $2^{\prime}, 20$ " per $3 \mathrm{~g} ; 4^{\prime}, 30^{\prime \prime}$ per $6 \mathrm{~g}$ e $7^{\prime}, 08^{\prime \prime}$ per $9-10 \mathrm{~g}$. La fase di decelerazione, ovviamente molto più rapila, è stata limitata a $9^{n}$ per $3 \mathrm{~g}$, $12^{\prime \prime}$ per 6 ge $17^{\prime \prime}$ per 9-10 g g.

Per tale esperimento ì stata impiegata ma centrifuga per piccoli animali già usata in precestenti ricerche da C. Varcal a Coll. (1 " 2). 
In via generale si è praticata l'esperienza negli stessi animali prima e dopo la deafterentazione delle zone rasosensibili chemio-e pressocentrici. Tale intervento è stato eseguito in anestesia locale

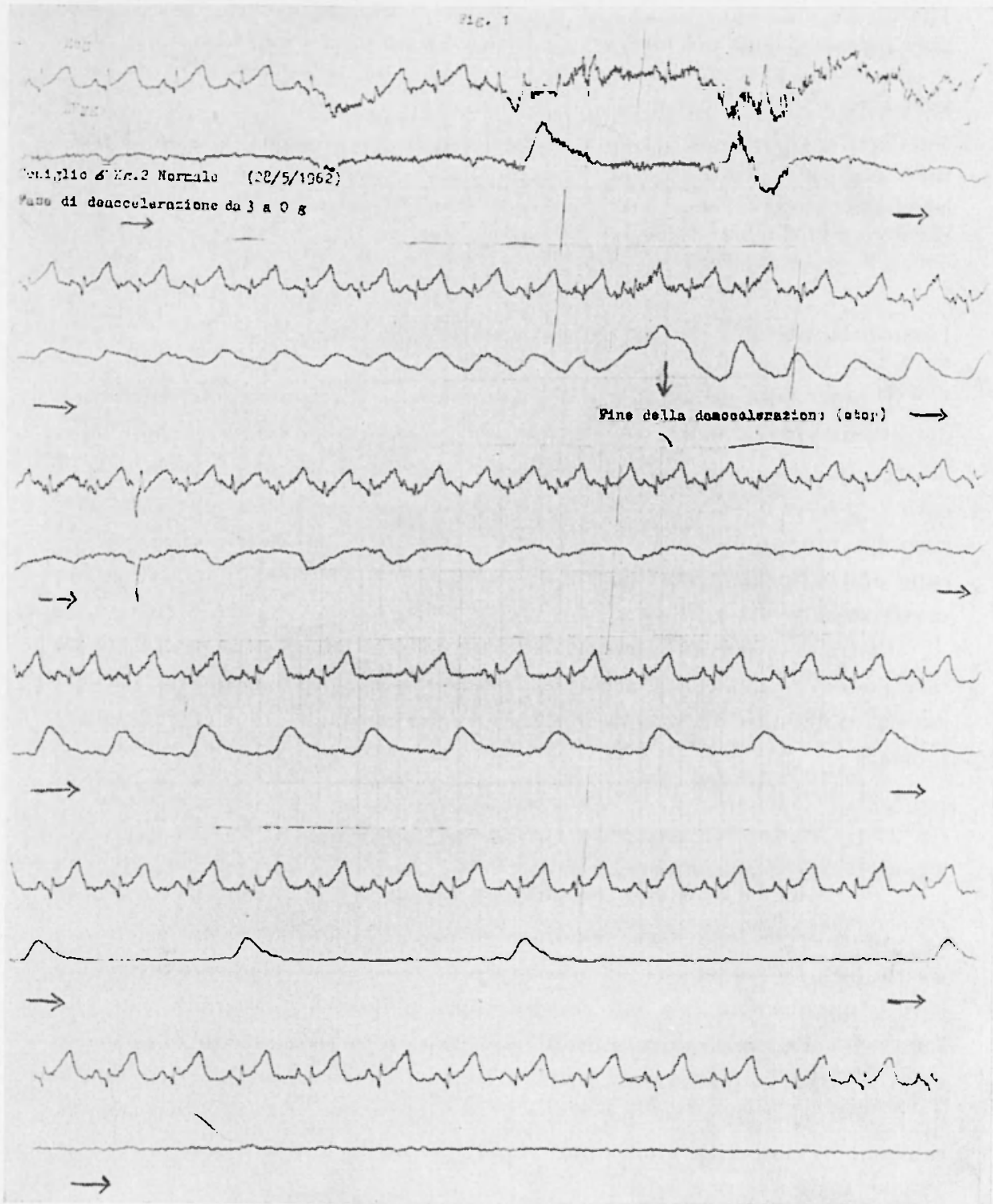

Fig. 1 
novocainica e previa intubazione tracheale per tracheotomia, sezionando successivamente e bilateralmente al collo i nn. grlosso-faringei (glomo a seno arotideo), di Cron ed i vaghi (zona cardio-aortia

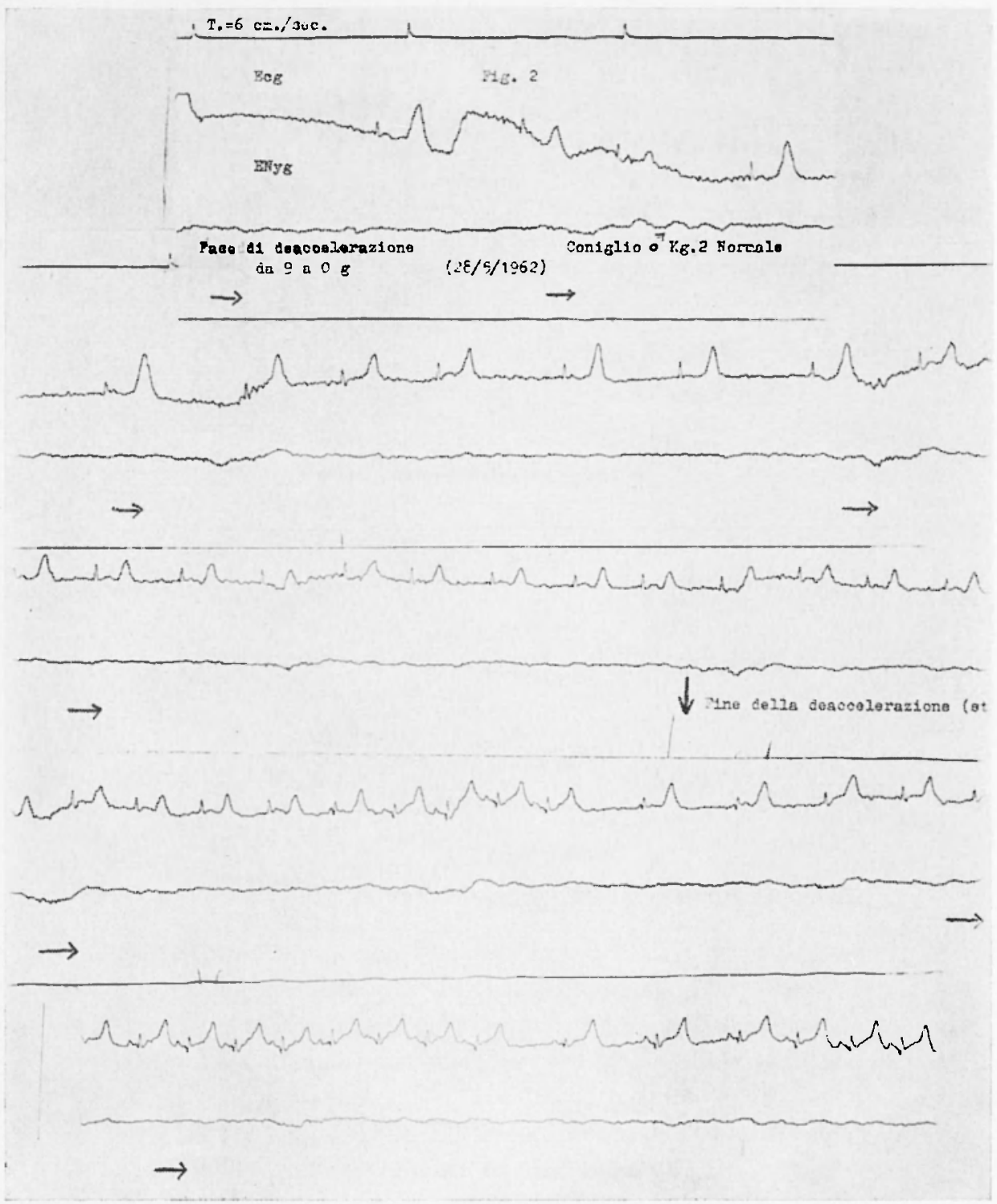

Fig. 2 
ed altri recettori eventualmente situati sullarteria polmonare). Gli animali renivano sottoposti alle accelerazioni tra sei e dodici ore dopo l'intervento.

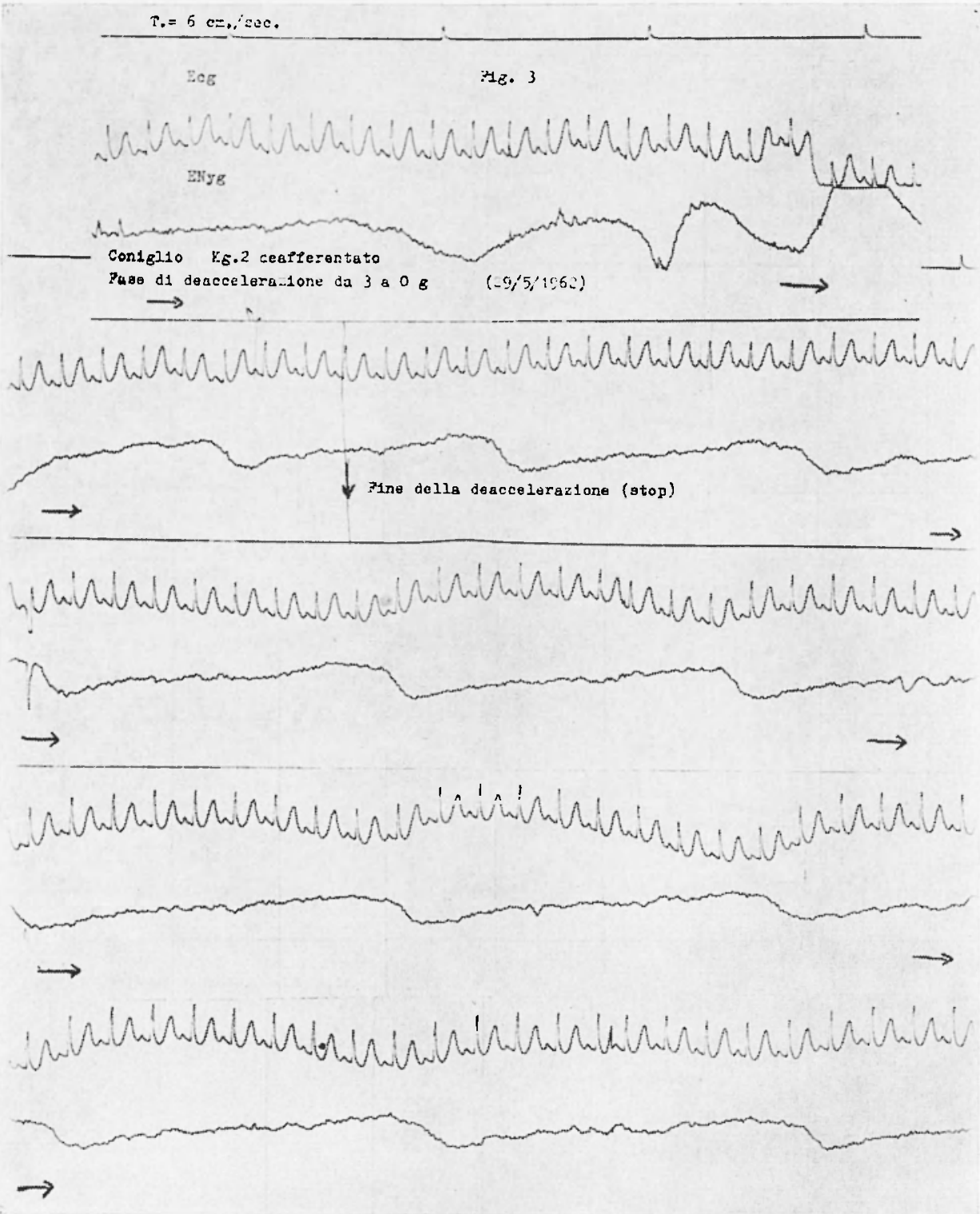

Wị. 3 
La centrifuga, a mezzo di contatti rotanti, ha jermesso fil rilievo del nistagmo orizzontale, anche durante la rotazione. applicando due aghi-elettrodi inseriti sottocute allangolo esterno della rima oculare.

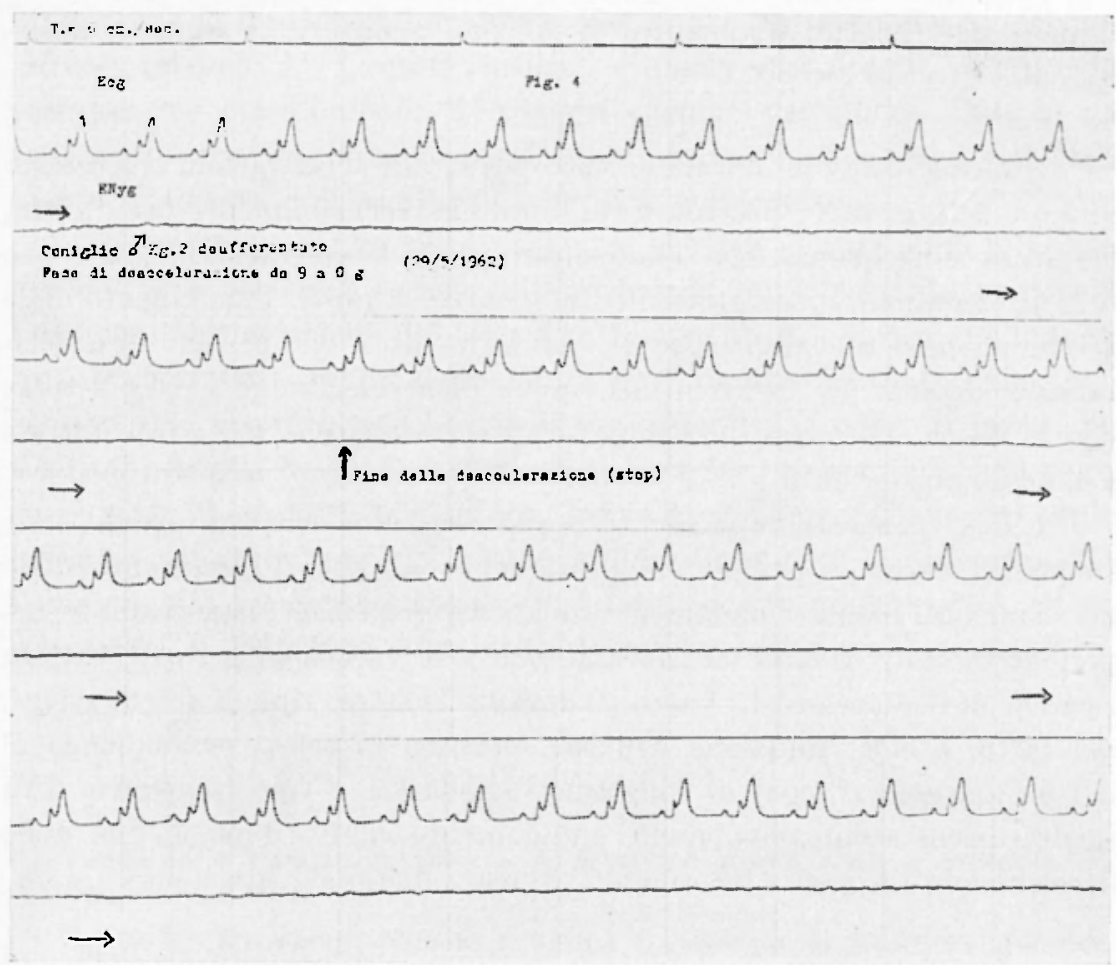

Fig. 4

mentre l'applicazione di aghi-elettrodi agli arti ha consentito il rilievo di una derivazione periferica $\left(D^{2}\right)$ elettrocardiografica. Ci si é serviti, per la registrazione contemporanea dei traceiati elettrocardiografico ed elettronistagmografico, di un elettroencefalografo tipo Galileo ad 8 canali con costante di tempo $=0,3$ ".

Nelle fignre 1, 2, 3 o 4 è illustrato un esempio completo delle esperienze condotte complessivamente su dieci animali. 
Risultati SPerinentali.

Dalle presenti esperienze-pilota (in quanto è nostra intenzione confinuale ricerche sull'argomento) si possono avanzare le seguenti osser'vazioni:

1) nel roniglio normale, sottoposto ad accelerazioni suceessive di 3,6 e 9-10 g, il Ny postrotatorio diminuisee sensibilmente per durata, ampiezza e frequenza con l'aumentare delle accelerazioni e, tra 6 e 9-10 g, scompare quasi totalmente mentre duante l'incremento delle aceelerazioni si rilevano scosse di a adattamento n. Sel periodo di accelerazione costante (90" per ogni massimale di accelerazione a 3,6 e 9-10 g) non si osservano scosse nistagmiche ad eccezione che nella fase ultima nell'aceelerazione di $3 \mathrm{~g}$.

L'Eeg, contemporaneamente registrato, dimostra variazioni della frequenza cardiaca a tipo di adattamento dumnte l'incremento delle aceelerazioni, mentre fondamentalmente la frequenza resta costante nel periodo di stato di essa. Si rilevano inoltre le variazioni già osservate in ricerche di C. Vacea ed L. Vacea (") dumante lo stesso tipo di accelerazioni, nel ratto, e cioè: rotazione dell'asse elettrico in senso orario, onda $P$ a tipo anossico e segni di solferenza coronariea a tipo ischemico. Tali modificazioni seompaiono molto mapidamente subito dopo la fine delle accelerazioni (in media intorno a $2^{\prime}-3^{\prime}$ dalla fine della rotazione).

2) nel coniglio deafferentato, sottoposto alle stesse accelerazioni su citate, nella fase costante di accelerazione a $3 \mathrm{~g}$, in genere, non si rilevano scosse nistagmiche ehe però compaiono, seppure alquanto ridotte di clumata, ampiezza a frequenza, alla cessazione della rotazione. A $6 \mathrm{~g}$ si nota un'ulteriore riduzione della risposta nistagmica che scompare addirittura a $9-10 \mathrm{~g}$.

Per quanto riguarda l'Ecg. si notano più frequenti e più intense variazioni della frequenza cardiaca sia a volte nel senso di ammento della frequenza stessa, sia nel senso della riduzione, specie a 6 e $9-10$ s, rispetto a quanto osservato prima della deafferentazione. I segni di softerenza miocarlica-coronarica su elencati si accentuano sensibilnente ed il ritorno alla norma, dopo la fine della rotazione, è più lento. Si è osservato anche a $9 \mathrm{~g}$ un caso di bloceo di branca sinistro (fig. 4). 


\section{Conclusioni.}

I risultati sperimentali su descritti dimostrano che stimoli afferenti periferici partenti dai pressocettori vasali senocarotidei e cardio-aortici influenzano la funzione labirintica evidenziando pertanto che connessioni nervose esistono fra i centri cardiaco e quello vasomotore, situati nella sostanza reticolare bulbare, ed i centri viciniori vestibolari. Data la natura vegetativa dei riflessi in parola $\left(^{3}\right)$ la connessione tra essi è verosimilmente effettuata dalla sostanza reticolare mesencefalica.

Le esperienze fanno rilevare inoltre che più elevate sono le accelerazioni meno intensa è la risposta vestibolare; esiste pertanto una soglia ottimale di stimolazione del labirinto. Inoltre appare chiaro che influenzano sicuramente la funzione labirintica impulsi partenti dalle zone reflessogene vasali, oltre che quelli provenienti dai ricettori propri del labirinto; infatti la deafferentazione delle zone vasosensibili riduce notevolmente la risposta nistagmica. Infine la deafferentazione dei centri bulbari dalle zone periferiche vasosensibili diminuisce la resistenza dell'animale alle accelerazioni trasversali tanto che in qualche caso, ad accelerazioni di $9-10 \mathrm{~g}$, si è verificata la morte dell'animale stesso.

\section{BIBLIOGRAFIA}

(1) Vacca C. e VACca L., Rivista di Medicina Aeronautica e Spaziale, 23, 34, Roma 1960.

(2) VACCa C., De Franciscis P. e VACCA L., Rivista di Medicina Aeronautica e Spaziale, 24, 501, Roma 1961.

( $\left.{ }^{3}\right)$ Koch C., Minerva Otorinolaring., 380-381, Torino 1960. 